\title{
OCCURRENCE OF Mesocyclops ogunnus ONABAMIRO, 1957 (COPEPODA CYCLOPOIDA) IN WATER BODIES OF SÃO PAULO STATE, IDENTIFIED AS Mesocyclops kieferi VAN DE VELDE, 1984
}

\author{
MATSUMURA-TUNDISI, T. and SILVA, W. M. \\ International Institute of Ecology, Rua Bento Carlos, 750, CEP 13560-660, São Carlos, SP, Brazil \\ Correspondence to: Takako Matsumura-Tundisi, International Institute of Ecology, Rua Bento Carlos, 750, \\ CEP 13560-660, São Carlos, SP, Brazil, e-mail: tmt.iie@iie.com.br, wmsilvax@starmedia.com \\ Received July 10, 2001 - Accepted October 24, 2001 - Distributed November 30, 2002
}

(With 4 figures)

\begin{abstract}
The aim of this work is clarify the identification of Mesocyclops ogunnus that occur in several reservoirs in the State of São Paulo and that was previously identified as Mesocyclops kieferi. These two species are closely related species with very similar characteristics. The differential characteristics are presented and the distribution of both species in the world is discussed.
\end{abstract}

Key words: Cyclopoda copepods, Mesocyclops ogunnus, distribution in São Paulo State, eutrophication.

\section{RESUMO}

Ocorrência de Mesocyclops ogunnus Onabamiro, 1957 (Copepoda Cyclopoida) nos corpos de água do Estado de São Paulo, identificado como Mesocyclops kieferi Van de Velde, 1984

Este trabalho teve por objetivo esclarecer a identificação da espécie Mesocyclops ogunnus que ocorre nos reservatórios do Estado de São Paulo e que havia sido identificada por vários autores como Mesocyclops kieferi. Estas duas espécies são muito semelhantes, diferindo-se em algumas características bastante sutis que são apresentadas neste trabalho. As duas espécies foram identificadas pela primeira vez em águas do continente africano, porém somente Mesocyclops ogunnus tem ocorrido na América do Sul e na América Central.

Palavras-chave: Copepoda Cyclopoida, Mesocyclops ogunnus, distribuição geográfica, eutrofização.

\section{INTRODUCTION}

The researchers who work with zooplankton ecology have faced many problems with identification of species since the taxonomic characteristics of plankton animals is very weak not showing any evident characteristics that define different species. In the case of Cyclopoida copepods Mesocyclops ogunnus (Onabamiro,
1957) and Mesocyclops kieferi (Van de Velde, 1984) both species occurring in Africa are very similar presenting the same shape of seminal receptacle differing only in certain details such as the spine pattern on the basipodite of antennae (A2), the presence or not of a row of minute spines on the posterior margin of the last abdominal segment or the presence of a row of spines on the basis of the maxillulary palp. 
Then the Cyclopoida species identified as Mesocyclops kieferi occurring in Barra Bonita reservoir registered for the first time in 1985 by Matsumura-Tundisi et al. (1990) it was actually Mesocyclops ogunnus. Also in the paper of Tundisi \& Matsumura-Tundisi (1994) there is reference of the Mesocyclops kieferi instead of Mesocyclops ogunnus.

The aim of this paper is to clarify the problem of identification of these two species and to record the correct Cyclopoida species occurring in the reservoirs of São Paulo State.

\section{MATERIAL AND METHODS}

The material examined originates from several reservoirs of São Paulo State. It was collected with a plankton net of $68 \mu \mathrm{m}$ fixed in formol $4 \%$, and the samples are stocked in the Sao Carlos Federal University Plankton Museum.

\section{Description of Mesocyclops ogunnus from Barra} Bonita reservoir and its difference from Mesocyclops kieferi

Mesocyclops ogunnus appeared in Barra Bonita reservoir around 1985 constituting the dominant Cyclopoida species of the reservoir. The adult female of this species is about $1.2 \mathrm{~cm}$ in size. It carries two egg sacs acquiring a special form (Fig. 1) and the seminal receptacle is very similar to that described for Mesocyclops kieferi by Van de Velde 1984.

Van de Velde, 1984, presented the anatomical differences between Mesocyclops ogunnus and Mesocyclops kieferi. The Fig. 3 shows these differential characteristics between the two species and Table 1 the explanation of these characters used to differ both species. The Fig. 4 shows the characteristics of the dissected pieces of the Mesocyclops ogunnus obtained from Barra Bonita reservoir.

Ecology and distribution of Mesocyclops ogunnus in reservoirs of São Paulo State and in the world Mesocyclops ogunnus has been found as a dominant Cyclopoida species of the most eutrophicated reservoirs of Médio Tietê River of São Paulo State such as Barra Bonita since 1985 identified as Mesocyclops kieferi (MatsumuraTundisi et al., 1990). Also in several articles and thesis produced the species was cited as Mesocyclops kieferi instead M. ogunnus (Tundisi \& MatsumuraTundisi, 1994; Tundisi, 1994; Rietzler, 1995; Rietzler et al., 1996; Rietzler \& Espíndola, 1998; Sonoda, 1998; Guntzel, 2000; Nogueira, 2001). The species was found in great number in Bariri and Ibitinga reservoirs both eutropicate ones constructed in the cascade in Tietê River (Fig. 2).

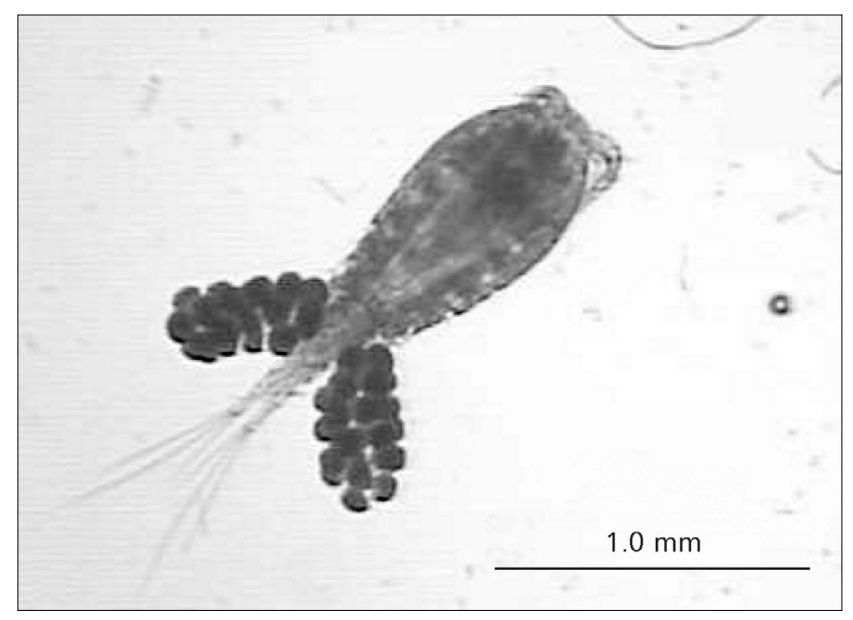

Fig. 1 - Picture of Mesocyclops ogunnus female with eggs sacs. 

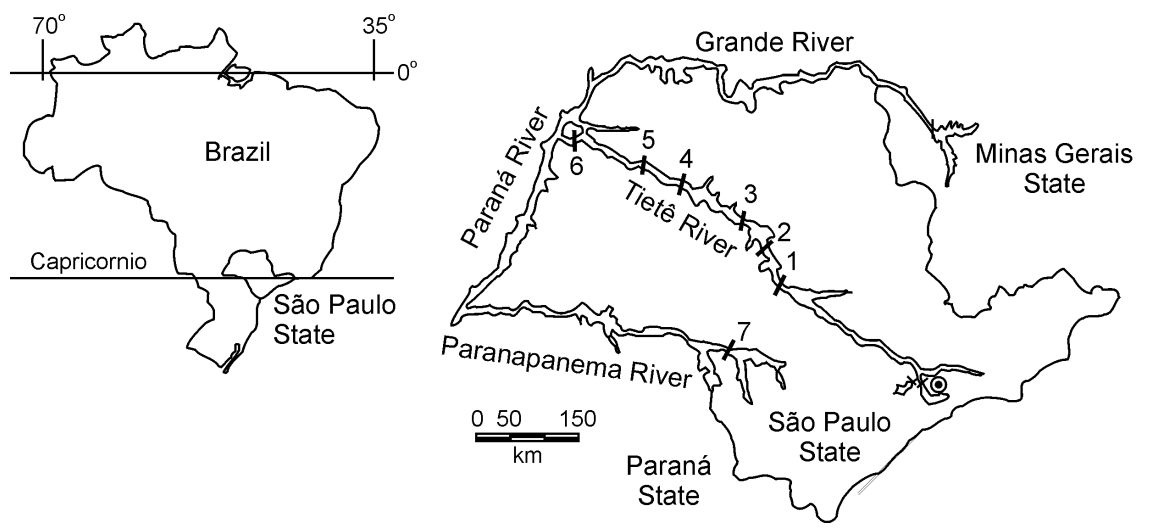

Reservoirs legends

1. Barra Bonita

2. Bariri

3. Ibitinga

4. Promissão

5. Nova Avanhandava

6. Três Irmãos

7. Jurumirim

Fig. 2 - Reservoirs of Tietê and Paranapanema rivers where Mesocyclops ogunnus occurred.

TABLE 1

Anatomical differences between Mesocyclops ogunnus and Mesocyclops kieferi by Van de Velde (1984).

\begin{tabular}{|l|l|l|}
\hline & Mesocyclops kieferi & Mesocyclops ogunnus \\
\hline A & $\begin{array}{l}\text { Antenna 2: caudal side: without row of spines on } \\
\text { distal portion. }\end{array}$ & $\begin{array}{l}\text { Antenna 2: caudal side: with row of transversal } \\
\text { spines on distal portion. }\end{array}$ \\
\hline B & Maxillulary palp: basis without row of spines. & Maxillulary palp: basis with row of spines. \\
\hline C & Basipodite of P4: with spines and hairs. & Basipodite of P4: without spines, only hairs. \\
\hline D & Last thoracic segment: without lateral row or hairs. & Last thoracic segment: with lateral row or hairs. \\
\hline D & Receptaculum seminis: lateral arms broad. & $\begin{array}{l}\text { Receptaculum seminis: lateral arms broad and } \\
\text { slightly curved backwards. }\end{array}$ \\
\hline E & $\begin{array}{l}\text { Last abdominal segment: fringed of spines, dorso } \\
\text { and ventral. }\end{array}$ & Last abdominal segment: without row of spines. \\
\hline E & Furca: with of row of spinules. & Furca: without of row of spinules. \\
\hline
\end{tabular}

At the other following reservoirs such as Promissão, Nova Avanhandava and Três Irmãos, which are less eutrophicate, the presence of Mesocyclops ogunnus has been registered, however not as a dominant species (Guntzel, 2000). In these reservoirs other species such as Thermocyclops decipiens constitute the main dominant species (Silva \& Matsumura-Tundisi, 2001). Mesocyclops ogunnus, which was described by Onabamiro (1957), is originated from the African lakes but the presence of this species has been registered in the other continents as Asia (Van de Velde, 1984), Central America (Suarez-Morales et al., 1999). In South America it was recorded in Brazil and was considered by Reid \& Pinto-Coelho (1994) as an introduced species with African fishes species. 
A
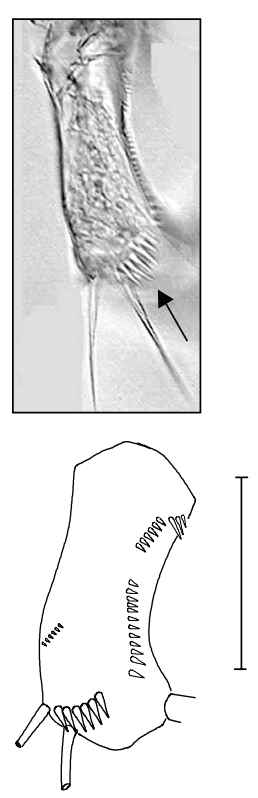

D
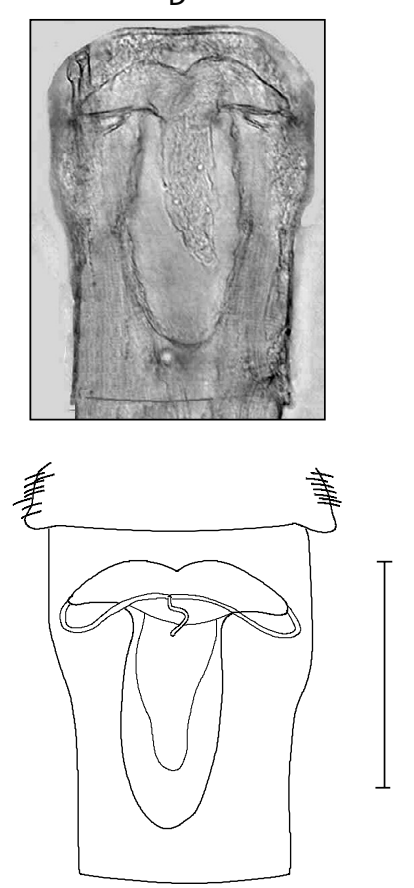

B
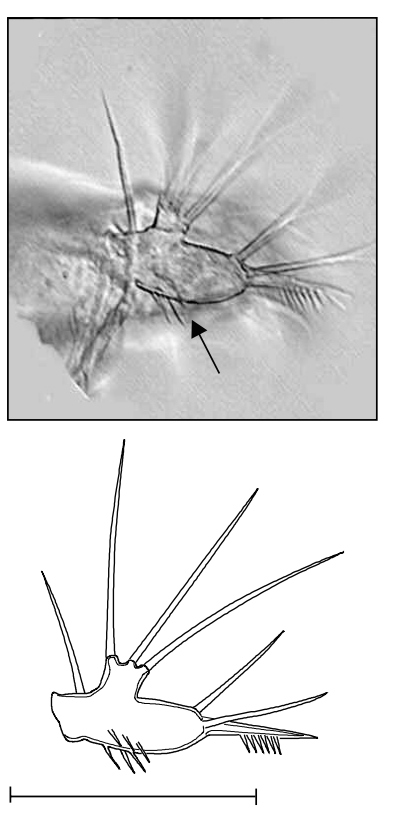

C
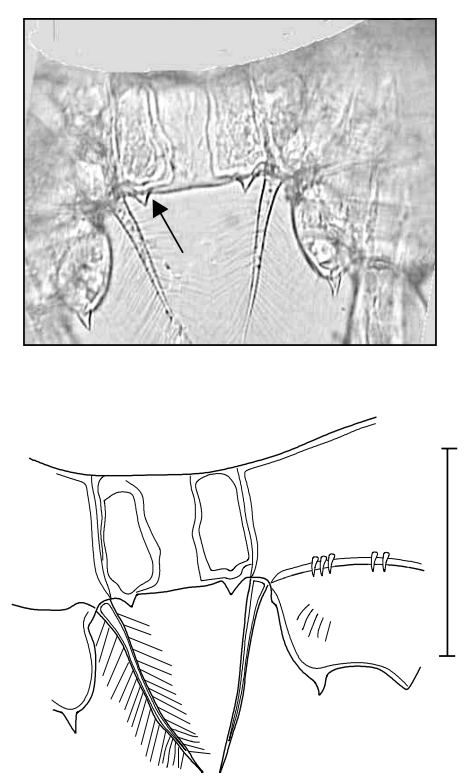

E
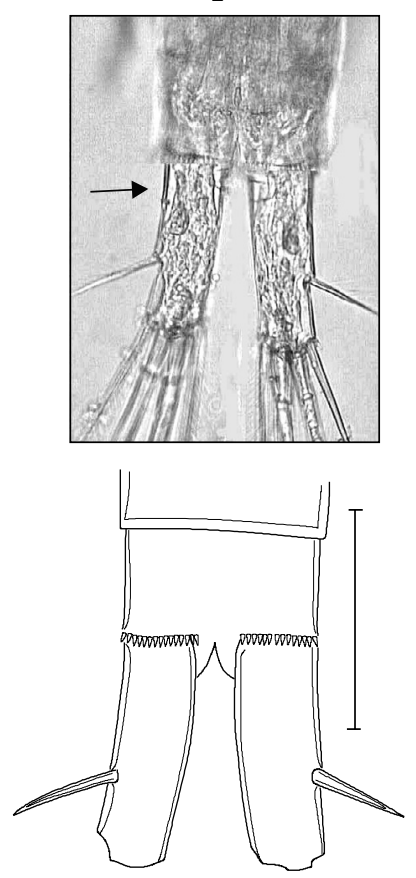

Scale $=1.0 \mathrm{~mm}$

Fig. 3 - Characteristics of Mesocyclops ogunnus from Barra Bonita Reservoir. A - Antenna 2: caudal side (arrow shows the transversal spinules row); B - maxillulary palp with row of spines on basis (arrow); C - lamela intercoxal (arrows shows the shape and size of proeminences on distal margin); D - genital segment; E - furca (arrow showing lack of spinules). 


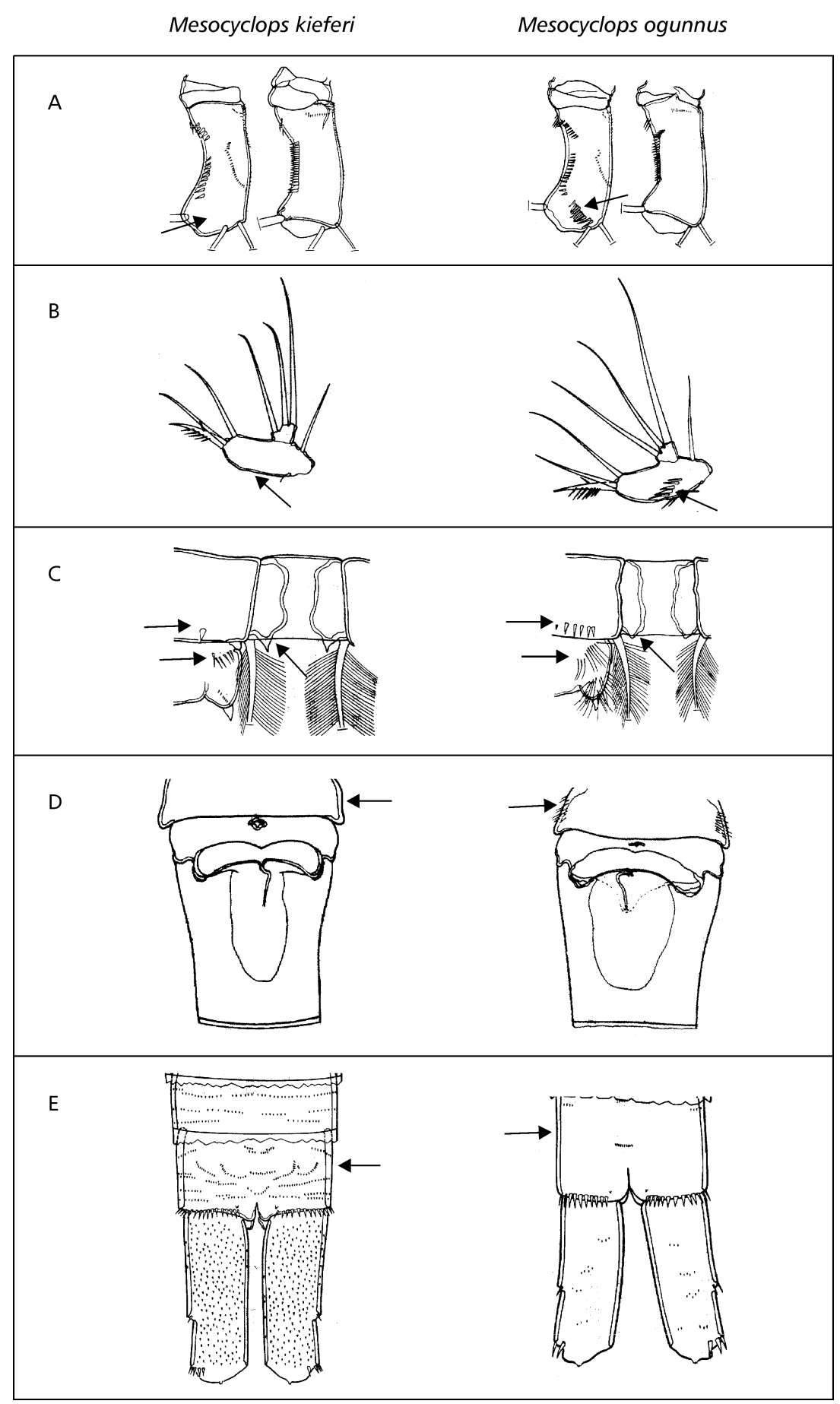

Fig. 4 - Differential characteristics between Mesocyslops kieferi and M. ogunnus (Van de Velde, 1984): A - basipodite of antenna 2, caudal and frontal side; B - maxillulary palp; C - connecting lamela and inner portions of coxa basipodite; D - last thoracic segment and genital segment; E - last abdominal segment and furca. The arrows indicate differences present by these species. 
Acknowledgments - The authors express their gratitude to FAPESP for the financial support. This work is part of BIOTA/ FAPESP - Virtual Institute of Biodiversity.

\section{REFERENCES}

GUNTZEL, A. M., 2000, Variações espaço-temporais da comunidade zooplanctônica nos reservatórios do Médio e Baixo Rio Tietê/Paraná, SP. Ph.D. Thesis, Universidade Federal de São Carlos, 280p.

MATSUMURA-TUNDISI, T., RIETZLER, A. C. \& ESPÍNDOLA, E. L. G., 1990, Predation on Ceriodaphnia cornuta and Brachionus calyciflorus by two Mesocyclops species coexisting in Barra Bonita Reservoir. Hydrobiologia, 198: 141-151.

NOGUEIRA, M. G., 2001, Zooplankton composition, dominance and abundance as indicators of environmental compartmentalization in Jurumirim Reservoir (Paranapanema River), São Paulo, Brazil. Hydrobiologia, 455(1): $1-18$.

REID, J. \& PINTO-COELHO, R., 1994, An afro continental Copepod, Mesocyclops ogunnus found in Brazil; with a new key to the species of Mesocyclops in South America and a review of intercontinental introductions of copepods. Limnologica, 24(4): 359-368.

RIETZLER, A. C., 1995, Alimentação, ciclo de vida e análise da coexistência de espécies de Cyclopoida na Represa de Barra Bonita. Ph.D. Thesis, Escola de Engenharia de São Carlos, Universidade de São Paulo, 385p.

RIETZLER, A. C. \& ESPÍNDOLA, E. L. G., 1998, Microcystis as a food source for copepods in a subtropical eutrophic reservoir. Verh. Intern. Verein. Limnol., 26: 2001-2005.
RIETZLER, A. C., MATSUMURA-TUNDISI, T. \& ESPÍNDOLA, E. L. G., 1996, Dinâmica das populações de Thermocyclops decipiens e Mesocyclops kieferi no reservatório de Barra Bonita em diferentes escalas de tempo. In: VIII Seminário Regional de Ecologia. Abstracts, São Carlos, SP.

SILVA, W. M. \& MATSUMURA-TUNDISI, T., 2001, Distribution and abundance of Cyclopoida populations in a cascade of reservoir of the Tietê River (São Paulo State, Brazil). Verh. Int. ver. Limnol. (in press).

SONODA, S. L., 1998, Estrutura da comunidade planctônica da região litorânea (compartimento Capivara) da Represa de Barra Bonita, SP. MSc. Thesis, Escola de Engenharia de São Carlos, Universidade de São Paulo, 140p.

SUAREZ-MORALES, E., MCLELLAND, J. \& REID, J., 1999, The planktonic copepods of coastal saline ponds of the Cayman Islands with special reference to the occurrence of Mesocyclops ogunnus Onabamiro, an apparently introduced Afro-Asian cyclopoid. Gulf Research Reports., 11: 51-55.

TUNDISI, J. G., 1994, Tropical South America: Present and Perspectives. In: Margalef, R. (ed.), Limnology Now: A paradigm of planetary problems. Elsevier Science, Amsterdam, pp. 353-424.

TUNDISI, J. G. \& MATSUMURA-TUNDISI, T., 1994, Plankton diversity in a warm monomictic lake (Dom Helvécio, Minas Gerais) and a polymictic reservoir (Barra Bonita): A comparative analysis of the Intermediate Disturbance Hipothesis. An. Acad. Bras. Ci., 66(1): 15-28.

VAN DE VELDE, I., 1984, Revision of the African species of the genus Mesocyclops Sars, 1914 (Copepoda: Cyclopidae). Hydrobiologia., 109: 3-66. 